\title{
Case-Finding in Korea
}

\author{
Sung Chin Kim, M.D. \\ Korean Institute of Tuberculosis, Korean National Tuberculosis Association \\ Seoul, Korea
}

-국문초록-

\section{우리나라 결핵관리 사업에 있어서의 환자발견 사업의 검토}

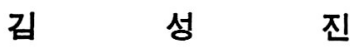

대한결핵협회 결핵연구원

전염원을 찾아내어 그 전염경로롤 차단하여야 함은 전염병 관리의 원칙이다. 결핵의 전염원이되는 결핵 환자에는 객담내 배 균상태에 따라 균음성 과 균양성 으로 구분된다. 균음성, 양성할 것없이 모든 결핵환자룰 발견하여 효과적으로 치료함이 가장 이상적이라 하겠다. 그러나 1975년도 제3차 전국결핵실태조사에서 나 타난 바와 같이 아직까지도 유병률이 높아 전인구의 $3.3 \%$ 인 $1,014,000$ 명의 결핵환자가 있고 균양성자만도 235,000 명에 달하고 있다. 우리나라는 한정된 재원으로 이 많은 환자를 단기간에 발견, 치료한다는 것은 불가능한 것이다. 따라서 균양성 환자롤 우선적으로 발견, 치료해야 함은 당면 과제의 하나이다.

국가결핵관리를 위한 환자발견 방법에 는 엑스선 환자발견과 객담검사 환자발견이 있다. 이두가지 방법에 는 각기 다른 장점이 있는데 엑스선 환자 발견은 조기에 많은 환자롤 한꺼번에 진단할수 있는 점을 지닌반 면에 객담 검진 환자 발견은 전염원 즉 균양성 환자를 발견하는데 절대적이다. 이점을 깊이 새기면서 저자 는 여기서 언제, 어디서, 어떻게, 어느것을 선택적으로 사용할 것인지에 대하여 논하고저 한다.

과거 10 년간의 환자발견 사업을 통하여 특히 상기한 궁극적 목표인 균양성 환자 발견을 우선한 객담검진 에 의한 환자 발견을 토대로 연구한 결과 다음과 같은 유리한 소견을 얻었다.

1. 매년 엑스선 환자발견에서 많은 엑스선 유소견자를 발견하지만 1975년도 실적을 보면 그중 발견된 균 양성 환자 $(14,300$ 명 ) 는 객담검 진 환자발견에서 $(30,020$ 명 ) 보다 적었으며 균양성 환자발견율은 각각 $0.74 \%$, 5. $1 \%$ 였다.

2. $\mathrm{X}$ 선 집단검진의 $\mathrm{X}$ 선 사진 한장만으로는 “활동성결핵"의 진단적의의가 적다.

3. 객담검사는 장비와 시설이 값싸고 간편하여 엑스선을 이용할 수 없는 도서지방 검진에 편리하다.

$\mathrm{X}$ 선 및 객담환자 발견에 있어서의 몇가지 경험과 특히 객담검진 환자발견을 효율적으로 수행해나가는 방안으로 고려해야 할점을 열거하면

1) 먼저 $\mathrm{X}$ 선이나 객담검진은 유증상자를 대상으로 하여 양성율을 높여야 하고

2) 환자발견 원척면에서 보건소 내소자를 통한 수동 균양 환자 발견율 $(8.7 \%)$ 이 가정 방문 수집검사의 능 동 발견율 $(4.3 \%)$ 보다 높아 더 효과적이기는 하지만 Dr. Toman 의 주장과는 달리 우리나라에서는 전자 보다 후자에서 전체균양성 발견환자수가 2 배가 넘고 있어 능동발견이 전염원 색출수단으로 매우중시된다.

3) 위에서와 같은 이치로 제 3 차 전국실태조사 결과 중상별 균양성 환자 발견율이 각혈에서 $11.0 \%$ 로서 객 담에서의 $3.5 \%$ 보다 훨씬 높지만 이에 반하여 총 발견 균양성 환자수는 각각 24 명, 94 명이므로 각혈 뿐만 아니라 객담도 환자 발견 사업면에서 중시되어야 한다.

본 논문의 요지는 제 10 차 국제항결핵연맹 동부지역희의 학술대회에서 발표하였음. 
4) 배양검사가.현단계로서는 이용도의 폭이 한정되어 있엉도말검사에서 발견처 못한 환자에 대한. 정밀 검사에 기여하는 정도이며 발견환자의 수적인면 과 전염원으로서의 전염성을 고려할때 도말검사가 무엇보다 도 중요하다 하겠다:

결론적으로 경체적이며 생산적인 객담검진 환자발견의 장점을 염두에 두고 위에 열거된 점을 고려하여 앞으로 이의 기술향상을 위하여 연구하는데 더욱 힘을 기울여야 할 것이다. 이와 같은 환자발견사업은 환 자 발견 자체만으로는 아무런 의의가 없으며 유효적절한 치료가 병행되어야 함은 말할 나위가 없다. 그래서 장기적 안목으로 보아 보건교육을 통하여 수동 환자발견에 융하도록 유도하여 나가는데 노력을 경 주하지 않으면 안될 것이며 이렇게 함으로서 효율적인 전염원 색출은 물론 환자스스로의 치료효과를 크게 개선하 여 나갈수 있을 것이다.

\section{Introduction:}

The primary objectives of any communicable disease control programme is to identify the infector population and insure that the chain of transmission is broken by effective and adequate treatment. The text of this paper will be directed towards the former objective, that being the methods employed in Korea in identifying the infector propulation; i.e. the infectious individuals.

Tuberculosis is a serious health problem which has still to be resolved in Korea as indicated in the 1975 prevalence survey.

In a developing country such as Korea where economics play a regulatory role in terms of programme capacity for administering effective and adequate treatment, priorities must be established such that the public health programme progresses towards the final ultimate goal, the control of the target disease. Therefore, finding and treating sputum positive cases has priority in the Korean National Tuberculosis Control Programme.

Case-finding is divided into two categories; $\mathrm{X}$-ray screening and sputum examination. We endeavour to utilize the previously mentioned types of case-finding in such a way as to reap the greatest benefits, keeping in mind the merits of each of the case-finding methods. X-ray case-finding is directed towards early detection through $\mathrm{X}$-ray. mass screening and sputum casefinding towards the discovery of the priority patients, the infectious patients.

Based on the experiences derived from sputum case-finding in Korea during the past ten years, I would like to discuss some aspects of the case-finding programme in Korea with emphasis on case-finding by sputum examination.

Case-finding by means of X-ray in Korea was begun in 1954 but only on a small scale. In 1962, X-ray case-finding was intensified on a nationwide scale. As shown in Figure 1, since 1971 the number of people examined yearly by $\mathrm{X}$-ray case-finding has steadily increased as has the number of

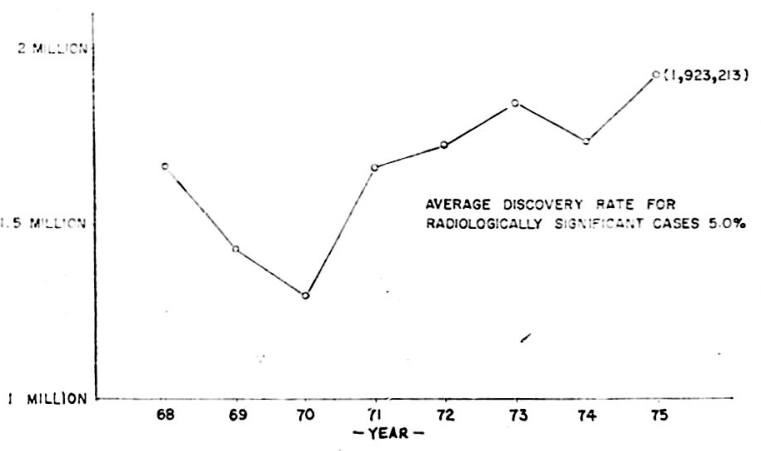

Fig. 1. No. of X-Ray Examination 1968-1975 
radiologically significant suspects discoveries. In $1975,1,923,213$ individuals were examined with a discovery rate of $5.4 \%$.

Case-finding by means of sputum examination was initiated in mid-1967 when the health aides were assigned at the district/ township level and has been found to be very efficient and productive in terms of discoveries. As shown in Figure 2, the number of discovered cases has been increasing yearly, while due to a higher degree of specimen selection the workload has been decreasing. In $1975,594,000$ sputum specimens were examined and 30,020, bacteriologically positive cases were detected, this being a discovery rate of $5.1 \%$.

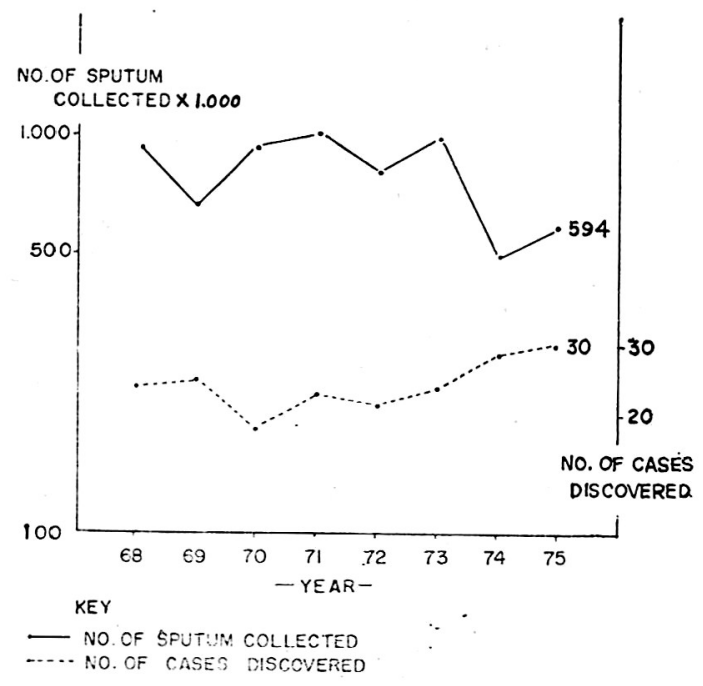

Fig. 2. Sputum Case-finding Unit $=$ No. $\times 10^{3}$

Our experience shows that X-ray casefinding discovers a large number of radiologically significant suspects but the number of infectious cases discovered is smaller than those discovered by sputum case-finding (Table 1). In terms of efficiency in discovery of infectious cases, $\mathrm{X}$-ray case-finding has a discovery rate of $0.74 \%$ as compared
Table 1. Bacteriologically Confirmed Cases of Pulm. TB by Case-finding Method with Cost Analysis (US\$)

Korea 1975

\begin{tabular}{lcc}
\hline & by X-ray & by Microscopy \\
\hline No. Discovered & 14.300 & 30.020 \\
Discovery Rate & $0.74 \%$ & $5.1 \%$ \\
Cost Per Case & $\$ 108.33$ & $\$ 6.14$ \\
\hline
\end{tabular}

Table 2. Two Types of Sputum Case of Sputum Case-Finding in Korea

1975

\begin{tabular}{lcc}
\hline \hline & $\begin{array}{c}\text { Passive } \\
\text { (Symptomatics } \\
\text { Reporting to } \\
\text { Health Centers) }\end{array}$ & $\begin{array}{c}\text { Active } \\
\text { (Symptomatics } \\
\text { Found by } \\
\text { Home visit) }\end{array}$ \\
\hline Total Examined & 108,000 & 486,000 \\
Yield & $8.7 \%$ & $4.3 \%$ \\
No. of Cases Discovered 9,000 & 21,000 \\
\hline
\end{tabular}

with $5.1 \%$ for sputum case-finding in 1975 .

Because of low cost and high case-yield, sputum case-finding is recommened in developing countries such as Korea. The cost. of case-finding per infectious patient discovered in US $\$$ is;

Sputum only $\$ 6.14$

$\mathrm{X}$-ray with bacteriological confirmation $\$ 108.33$

That is, the ratio between the cost of finding an infectious case by means of $\mathrm{X}$ ray case-finding to finding an infectious: case by sputum case-finding is $18: 1$. An additional advantage of sputum case-finding is the convenience with which the necessary equipment may be transported to remote areas.

Table 2 illustrates that sputum examinations performed at the health center on self-presenters or passive case-finding has a higher yield of infectious cases than sputum collectcd through home visiting or active case-finding. The discovery rates for $\mathrm{pa}-$ 
Table 3. Prevalence of Tubeculosis-Symptomatic vs Non-Symptomatic from 1975 Prevalence Survey

Korea

\begin{tabular}{lcc}
\hline & Symptoms & No Symptoms \\
\hline & $13.8 \%$ & $86.2 \%$ \\
$\begin{array}{l}\text { Radiologically Suspect } \\
\text { Tuberculosis }\end{array}$ & $9.2 \%$ & $2.4 \%$ \\
$\begin{array}{l}\text { Bacteriologically Confirmed } \\
\text { Cases (culture) }\end{array}$ & $3,0 \%$ & $0.41 \%$ \\
Smear Positive Cases & $2.2 \%$ & $0.20 \%$ \\
\hline
\end{tabular}

Sample Size 27.090

ssive case-finding and for active casefinding were $8.7 \%$ and $4.3 \%$ respectively. This difference may be attributed to the quality of the specimen and the nature of the examinee. In other words, self-presenters are frequently more grossly symptomatic than these approched by health aides at home visits.

Nevertheless, the total number of cases discovered by each method should not be overlocked. 21, 000 cases were discovered by active case-finding while only 9,000 were discovered by passive case-finding in 1975 .

Certain authorities have stated that passive case-finding is more effective than active case-finding. Our experiences in $\mathrm{Ko}^{-}$ rea indicate that passive case-finding is more efficient than active case-finding but less effective in terms of the number of priority patients discovered.

I would like to focus your attention on c srtain results from a study of sputum casefinding (table 3 ).

In the 1975 prevalence survey, study of the prevalence of tuberculosis in symptomatic and non-symptomatic subjects was done. In the sample population, $13.8 \%$ showed one or more symptoms of tuberculosis whereas $86.2 \%$ displayed no symptoms. The preva-
Table 4. Prevalence of Tuberculosis by Symptom (1975 Prevalence Survey)

Korea

\begin{tabular}{lrc}
\hline \hline & Sputum & Hemoptysis \\
\hline Frequency in Survey & $10.0 \%$ & $0.8 \%$ \\
Radiological Prevalence Rate & $9.9 \%$ & $21.1 \%$ \\
Bacteriological Prevalence Rate & $3.5 \%$ & $11.0 \%$ \\
$\begin{array}{l}\text { Bacteriologically Pos. } \\
\text { Cases Discovered }\end{array}$ & 95 & \multicolumn{2}{c}{24} \\
\hline
\end{tabular}

lence rate for radiologically significant $:$ suspects was $9.2 \%$ for symptomatics, and $2.4 \%$ for non-symptomatics while the bacteriological prevalence rates were $3.0 \%$ and $0.41 \%$ respectively. These results illustrate that efficiency in terms of case-yield can be greatly increased by making symptomatic suspects the focus for case-finding activities.

In the same study (table 4) the prevalence of tuberculosis by symptom was analyzed. Due to the time limitation, I have selected only two of symptom categories for this discussion. Of all those individuals tested $10 \%$ complained of the symptom of increased sputum production while $0.8 \%$ displayed haemoptysis. In the increased sputum production-symptom category a radiological prevalence rate of $9.9 \%$ and a bacteriological positive rate of $3.5 \%$ was noted. The haemoptysis symptom category showed a $21.1 \%$ radiological rate and a bacteriological positive rate of $11.0 \%$, As indicated here, higher radiological and bacteriological positive prevalence rates by symptom were noted, than for the increased sputum production category but the actual number of scorings in the other symptom categories was small. For example, the bacteriologically positive cases discovered in the symptom categories of sputum and haemoptysis 
Table 5. No of Patients Discovered by Direct L. Microscopy and Culture in 1975

\begin{tabular}{lcc}
\hline \hline & Smear & Culture \\
\hline No. Examined & 594,601 & 53,779 \\
Discovery Rate & $5.1 \%$ & $6.6 \%$ \\
\hline
\end{tabular}

was 95 and 24 respectively. "Therefore we should not overlook those symptoms which have a greater frequency within the population because they would be less efficient in terms of rates, since it is desired to find the maximum number of cases through case-finding.

Finally, I would like to share with you some information concerning microscopy and culture as well as their use in the Korean National Tuberculosis Programme(table 5). In 1975 a total of 594,601 smears exsamined and 53.779 cultures done. The discovery rates were $5.1 \%$ and $6.6 \%$ respectively. In actual numbers(Figure 3) 30,020 infectious patients were discovered by microscopy and 3,575 additional infectious cases were discovered by culture. From the 1975 prevalence survey it was determined that an additional 14, 668 bacteriological positive cases could have been discovered if financial determinants did not limit culturing facilities. However, in terms of infectivity case-finding by microscopy should have priority, especially in those instances where economic factors must dictate priorities as is commonly seen in developing countries.

In conclusion, we should, in the future, continue to research and improve our technical capabilities and utilize the previously discussed categories of case-finding, keeping in mind the merits of lowcost and high case-yield of sputum case-finding.

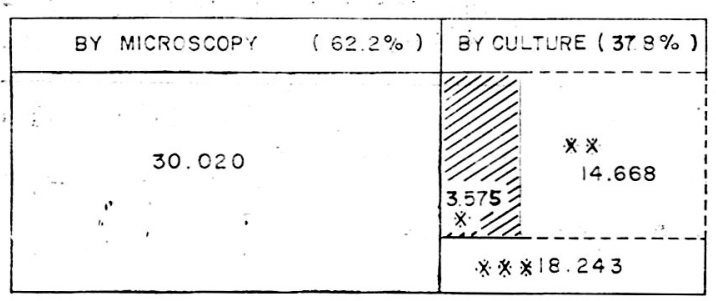

* actual no. discovered

* * ESTIMATED NO. DISCOVERABLE IF CULTURE FACILITIES AVAILABLE

*** Projected Total No. of Discovarable Cases by Culture

Fig. 3. No. of Patients Discovered by Microscopy and Culture 1975

Future long range Public Health Programs in developing countries should, keeping in mind that passive sputum case-finding is more efficient than active sputum casefinding, stress health education. In this manner the general population's awareness of the target disease and treatment facilities available may increase the proportion of self presenters within the program. A program emphasizing passive sputum casefinding will, in the long run, free more auxiliary health center personnel for case management. In this way, not only can we increase the efficiency of and the number of cases discovered by case-finding, but also improve the cure rate within the program. This is a very important point because only finding the patient is not sufficient. He must also be cured for a disease control program to be effective.

\section{References}

1. S. C. Kim: Case-finding in the Korean National Tuberculosis Programme, Reported at XXIII International Tuberculosis Conference of 
IUAT, Mexico 1975

2. Hsiao-Wen Luan: A New Case-Finding Programme in a Region of Taiwan, Tubercle 55: 121-127, 1974

3. K. Toman: Mass Radiography: WHO Chronicle, 30:51-57, 1976.

4. J.C. Tao: Problems of Organizing Case-Finding by Sputum Examination-Training, Supervision and Motivation of Personnel, 6 August 1969.

5. Hsin-Tseh Lin: Tuberculosis Control in the Republic of Korea, Final Report to WHO, 24 March 1962-31 December 1973.

6. S. C. Kim: Tuberculosis and Its National Control Programme in Korea, The Journal of the Korean Medical Association, 19(8): 604-6111, 1976.
7. K. S. Cho and S. C. Kim: Evaluation of Microscopic Techinque of Microscopists, Tuberculosis and Respiratory Diseases(Korean), 23(1): 18-24, 1976.

8. S. C. Kim: Laboratory Service in Korea, $B u-$ lletin of the International Union Against Tuberculosis, Vol. XLIX, Supplement No. 1, 192-193, 1974.

9. Ministry of Health and Social Affairs, Republic of Korea: Year Book of Public Health and Social Statistics, 1974.

10. Ministry of Health and Social Affairs, Republic of Korea: National Tuberculosis Programme, 1976.

11. Ministry of Health and Social Affairs, Korean National Tuberculosis Association: Result on the 3 rd TB Prevalemce-Survey in Korea, 1975. 